\title{
Hereditary angioedema
}

\author{
Helen Lesser ${ }^{1}$ (D) and Jason E. Cohn ${ }^{2^{*}}$
}

\begin{abstract}
A 14-year-old African American female presented to the emergency department with spontaneous, sudden-onset lip swelling for $1 \mathrm{~h}$. On examination, there was significant water-bag edema of the upper lip extending to the philtrum and premaxilla. Nasopharyngeal laryngoscopy revealed a patent airway without edema. She was initiated on intravenous dexamethasone, famotidine, and diphenhydramine, after which her edema improved but did not resolve. She was subsequently transferred to a local pediatric hospital and upon further testing she was found to have a C1 esterase inhibitor de novo gene mutation. Angioedema causes localized, non-pitting edema of the dermis, subcutaneous and submucosal tissue, and often manifests in the lips, face, mouth, and throat. Signs of laryngeal involvement include change in voice, stridor, dysphagia, and dyspnea. When laryngeal edema is present, it may necessitate definitive airway management and patients should be monitored in the intensive care unit.
\end{abstract}

Keywords: Angioedema, Hereditary angioedema, Lip swelling, Pediatric otolaryngology

\section{Case presentation}

A 14-year-old African American female presented to the emergency department with spontaneous, suddenonset lip swelling (upper greater than lower lip) for 1 h. On examination, there was significant water-bag edema of the upper lip extending to the philtrum and premaxilla (Fig. 1). The patient and her mother indicated that she did not have any food allergies nor did she have any new or unusual exposures. There was no family history of angioedema. Nasopharyngeal laryngoscopy revealed a patent airway without edema. She was initiated on intravenous dexamethasone, famotidine, and diphenhydramine which improved her edema but did not completely resolve it. She was subsequently transferred to a local pediatric hospital and upon further testing she was found to have a $\mathrm{C} 1$ esterase inhibitor de novo gene mutation. She was scheduled to see an allergist as an outpatient for further management.

\footnotetext{
* Correspondence: jcohnmed2729@gmail.com

${ }^{2}$ Department of Otolaryngology-Head and Neck Surgery, Division of Facial Plastic Reconstructive Surgery, Louisiana State University Health Sciences Center, 1501 Kings Highway, Shreveport, LA 71103, USA

Full list of author information is available at the end of the article
}

\section{Diagnosis}

The prevalence of hereditary angioedema is very low, affecting 1/10,000-50,000 people. Hereditary angioedema causes localized, non-pitting edema of the dermis, subcutaneous and submucosal tissue, and often manifests in the lips, face, mouth, and throat. Two main pathways contribute to angioedema-the most immediate pathway (minutes to hours) is mediated by mast cell and basophil degranulation causing urticaria and pruritus, while the more delayed pathway (hours-days) is mediated by kinin. Hereditary angioedema may be considered in the case of angioedema without urticaria, as this rare form involves the latter pathway. Unlike the acquired type, hereditary angioedema is bradykinin-mediated only and is mostly caused by mutations to $\mathrm{C} 1$ inhibitor $(\mathrm{C} 1 \mathrm{INH})$, which, through the complement pathway, leads to low $\mathrm{C} 4$ levels and eventually uninhibited bradykinin. Hereditary angioedema may be diagnosed by measuring $\mathrm{C} 4$ and $\mathrm{C} 1 \mathrm{INH}$ levels [1].

Hereditary angioedema typically presents before adulthood as recurrent angioedema attacks without pruritus or urticaria. These episodes usually last 2-5 days without treatment, with no associated triggers and with a possible family history of angioedema. Initial management

C C The Author(s). 2021 Open Access This article is licensed under a Creative Commons Attribution 4.0 International License, which permits use, sharing, adaptation, distribution and reproduction in any medium or format, as long as you give appropriate credit to the original author(s) and the source, provide a link to the Creative Commons licence, and indicate if changes were made. The images or other third party material in this article are included in the article's Creative Commons licence, unless indicated otherwise in a credit line to the material. If material is not included in the article's Creative Commons licence and your intended use is not permitted by statutory regulation or exceeds the permitted use, you will need to obtain permission directly from the copyright holder. To view a copy of this licence, visit http://creativecommons.org/licenses/by/4.0/ The Creative Commons Public Domain Dedication waiver (http://creativecommons.org/publicdomain/zero/1.0/) applies to the data made available in this article, unless otherwise stated in a credit line to the data. 

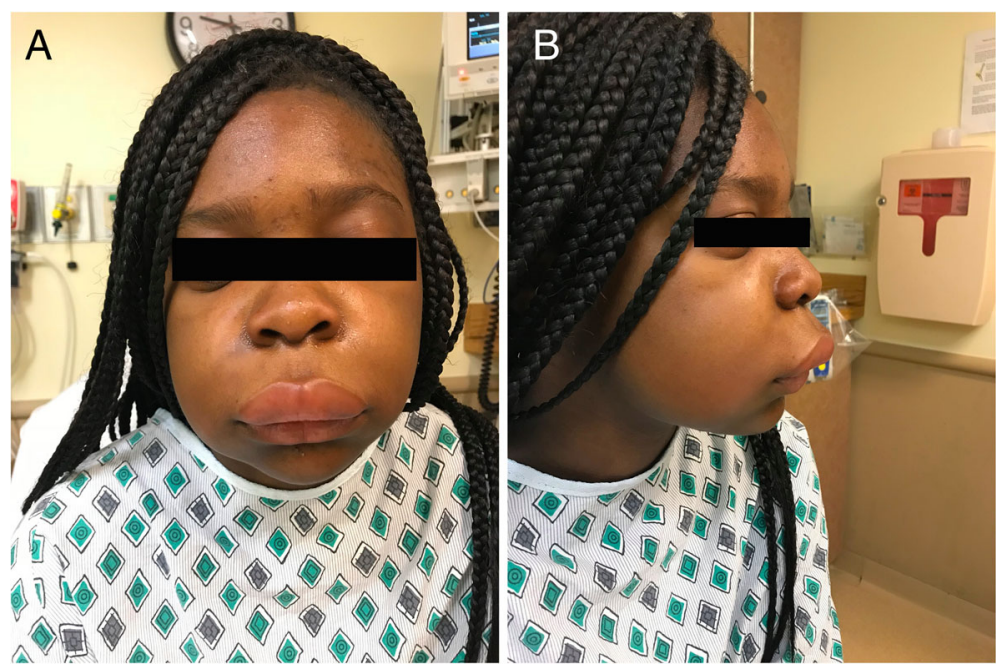

Fig. 1 A 14-year-old female with spontaneous lip swelling (upper > lower) extending to the philtrum and premaxilla on frontal (A) and lateral (B) views

requires assessing the airway, because edema may rapidly progress. Airway obstruction occurs in up to $15 \%$ of cases, accounting for a large portion of morbidity and mortality [2].

Signs of laryngeal involvement include change in voice, stridor, dysphagia, and dyspnea. In these cases, fiberoptic visualization should be emergently performed and may reveal pharyngeal or more ominously, laryngeal edema involving the vocal folds, epiglottis, aryepiglottic folds, or arytenoids. When laryngeal edema is present it may necessitate definitive airway management [3]. If suspecting a need for intubation, laryngoscopy may be performed with endotracheal tube loaded onto it to facilitate fiberoptic intubation. Patients should be monitored in the intensive care unit. Other treatments include $\mathrm{C} 1$ inhibitors, bradykinin $B_{2}$ receptor antagonist, and kallikrein inhibitors to block the bradykinin activity. If these are unavailable, fresh frozen plasma may be used to replace $\mathrm{C} 1$ inhibitor $[4,5]$. Unlike histamine-mediated angioedema, the hereditary form typically does not respond to antihistamine, corticosteroids, and epinephrine.

\section{Acknowledgements}

Not applicable

\section{Authors' contributions}

All authors read and approved the final manuscript.

\section{Funding}

None

Availability of data and materials Not applicable

\section{Declarations}

Ethics approval and consent to participate Not applicable

\section{Consent for publication}

Not applicable

\section{Competing interests}

The authors declare that they have no competing interests.

\section{Author details}

${ }^{1}$ Department of Otolaryngology-Head and Neck Surgery, Philadelphia College of Osteopathic Medicine, 4190 City Line Avenue, Philadelphia, PA 19131, USA. ${ }^{2}$ Department of Otolaryngology-Head and Neck Surgery, Division of Facial Plastic Reconstructive Surgery, Louisiana State University Health Sciences Center, 1501 Kings Highway, Shreveport, LA 71103, USA.

Received: 18 September 2020 Accepted: 30 June 2021

Published online: 29 July 2021

\section{References}

1. Kim SJ, Brooks JC, Sheikh J, Kaplan MS, Goldberg BJ. Angioedema deaths in the United States, 1979-2010. Ann Allergy Asthma Immunol. 2014;113(6): 630-4. https://doi.org/10.1016/j.anai.2014.09.003.

2. Bork K, Hardt J, Witzke G. Fatal laryngeal attacks and mortality in hereditary angioedema due to C1-INH deficiency. J Allergy Clin Immunol. 2012;130(3): 692-7. https://doi.org/10.1016/j.jaci.2012.05.055.

3. Bentsianov BL, Parhiscar A, Azer M, Har-el G. The role of fiberoptic nasopharyngoscopy in the management of the acute airway in angioneurotic edema. Laryngoscope. 2000;110(12):2016-9. https://doi.org/1 0.1097/00005537-200012000-00007.

4. Bowen T, Cicardi M, Farkas H, et al. 2010 International consensus algorithm for the diagnosis, therapy and management of hereditary angioedema. Allergy, Asthma Clin Immunol. 2010;6:24.

5. Wilkerson RG, Manini A, Scott J. Angioedema in the emergency department: an evidence-based review. Emerg Med Pract. 2012;14(11):1-21.

\section{Publisher's Note}

Springer Nature remains neutral with regard to jurisdictional claims in published maps and institutional affiliations. 